\title{
Remittances, Governance and Economic Growth: Empirical Evidence from MENA Region
}

\author{
Wadad Saad ${ }^{1} \&$ Hassan Ayoub ${ }^{2}$ \\ ${ }^{1}$ Doctoral School of Law, Political, Administrative and Economic Sciences, Lebanese University, Lebanon \\ ${ }^{2}$ Faculty of Economics and Business Administration, Lebanese University, Lebanon \\ Correspondence: Wadad Saad, Doctoral School of Law, Political, Administrative and Economic Sciences, \\ Lebanese University, Sin el Fil, Lebanon. Tel: 961-3-880-036. E-mail: wsaad96@hotmail.com and \\ wsaad@ul.edu.lb
}

Received: June 4, 2019

Accepted: June 19, 2019

Online Published: June 25, 2019

doi:10.5539/ijef.v11n8p1

URL: https://doi.org/10.5539/ijef.v11n8p1

\begin{abstract}
In this study we examine the effects of remittances and governance on economic growth in ten MENA countries. We choose these countries because they have relatively stable political situations. Using annual data from the World Bank over the period 2002-2017, we estimate panel autoregressive distributed lag (ARDL) models due to the existence of mixed levels of integration among series involved in this study. Control variables such as gross capital formation, consumption per capita and openness among others are integrated in these models. A governance composite is computed using the 6 governance indicators from the world bank. These indicators are used individually in different ARDL models with their interactions with the remittances to explore their impact on economic growth. The findings indicate a negative impact of the remittance on economic growth in the quasi-totality of the models. However, while governance composite shows a positive impact on economic growth, taking into consideration the dimensions of governance leads to conflicting results.
\end{abstract}

Keywords: remittances, governance, economic growth, ARDL model, MENA countries

\section{Introduction}

Since 2004, the Development Committee of the World Bank and the IMF have emphasized the importance of remittances and their effects on the real economy. MENA countries are particularly affected by international emigration because of the substantial growth of remittances from their emigrants. Indeed, these transfers have been on an upward trend since 2011. They increased gradually from $1.43 \%$ of GDP in 2011, to reach $6.5 \%$ in 2017 (World Bank, 2018). This rate is among the highest in the world. The question is: do remittances contribute to economic growth in the MENA region? Our hypothesis is that good governance could promote the positive impact of remittances on economic growth.

This question is relevant in the context of those countries facing a deficit of foreign direct investment and savings, much of which is characterized by political instability, macroeconomic dysfunctions, insecurity, bureaucratic red tape and corruption. These structural problems may compromise the impact of these transfers on the economic growth of these countries. Despite the recognition of the role that these problems can play, very little researches, to our knowledge, dynamically assess the role of remittance interaction with governance in growth in the context of MENA countries. This spurs Catrinescu et al. (2009) to emphasize that governance was an element that was largely omitted in the literature.

From an economic development point of view, it is important to know whether remittances are used for consumption or channeled into investments. As a results, we can distinguish between productive and unproductive remittances. In the former, remittances are mainly spent on consumption with a small portion addressed to unproductive saving and investments, essentially in housing, land and jewelry (Chami, Fullenkamp, \& Jahjah, 2003). The latter assumes a positive impact of remittances on economic growth since they enhance investments in physical and human capital (Edwards \& Ureta, 2003).

Thus, remittances could be significantly correlated with other variables that, in turn, affect economic growth. As a result, it becomes useful to know the mechanisms by which remittances interact with other explanatory variables to affect economic growth. 
Our study aims to analyze the role of these transfers in economic growth by referring specifically to MENA countries and by integrating a variable of interaction between transfers and governance in an ARDL panel model. In particular, we wish to test whether generalized good governance is an important condition for a more favorable impact of transfers on economic growth in the MENA countries.

This paper is organized as follows: section 2 is devoted to the review of the literature on the impact of remittances on economic growth. Section 3 presents the economic growth and remittances in the countries involved in this study. As to section 4, it displays the methodology adopted in this research. With respect to section 5, it presents the obtained results. Finally, the last section concludes this study.

\section{Literature Review}

Two approaches have been developed to analyze the transfer of funds. The first concerns the study of their impact (Note 1). While the second highlights the analysis of their determinants. This second line of research has been divided into microeconomic and macroeconomic approaches (Docquier \& Rapoport, 2003). The microeconomic approach focuses on the socio-demographic characteristics (Note 2) of migrants and their families (Agarwal \& Horowitz, 2002; Germenji, Beka, \& Sarris 2001; Gubert, 2002; Dorantes \& Pozo, 2006). While the second approach takes into account the macroeconomic variables of both host and home countries (El-Sakka \& McNabb, 1999; Faini, 1994; Glytsos, 1997; Higgins, Hysenbegasi, \& Pozo, 2004; Niimi et al., 2010, 2012; Singh, 2012; Yuni, Omeje, \& Asogwa, 2013).

Some contributions have focused on the positive effect of transfers on economic growth through several variables: the reinforcement of the health service (Adams, 2004), the increase in the investment rate (Woodruff \& Zenteno, 2007; Giuliano \& Ruiz-Arranz, 2009), the enhancement of the financial development (Stark \& Lucas, 1988; Lucas, 2005), the accumulation of human capital ((Edwards \& Ureta, 2003; Rapoport \& Docquier, 2005; Calero et al., 2009; Combes \& Ebeke, 2011), the improvement in total factor productivity (Leon-Ledesma \& Piracha, 2004; Chami et al., 2003; Abdih et al., 2012), poverty reduction (Akobeng, 2016; Majeed, 2015; Adams Jr \&Cuecuecha, 2013).

While others studies have emphasized the negative impact of remittances on economic growth of the recipient country through the following variables: the increase in the external deficit and the disequilibrium balance of payments (Kireyev, 2006; Lueth \& Ruiz-Arranz, 2007). The reduction of labor supply (Chami et al., 2008; El-Hamma, 2017), the decline in exports and employment (World Bank, 2006), the creation of moral hazards (Gubert, 2002), the increase in the inflation rate (Khan \& Islam, 2013), the reduction of the country's competitiveness (Dutch syndrome) (Amuedo-Dorantes, Pozo, \& Vargas-Silva, 2010; Bourdet \& Falck, 2006; Acosta, Lartey, \& Mandelman, 2009).

It is clear that these contributions have analysed the positive and negative direct effects of remittances on economic growth. However, it is important to investigate the impact of the interaction of remittances with other variables on economic growth such as governance in all its aspects. Certain studies have considered the interaction of remittances with other variables that include: financial development (Giuliano \& Ruiz-Arranz, 2009), institutional quality (Abdith et al., 2008, Singh, Haacker, \& Lee, 2009), human capital, political institutions, and financial development, Fajnzylber et al. (2008), good governance (Catrinescu et al., 2008; Giuliano \& Ruiz-Arranz, 2009), financial development and institutional quality (Bjuggren et al., 2010), banking efficiency (Bettin \& Zazzaro, 2012), stability of the economic growth regime (De Haas, 2008, Adams \& Klobodu, 2016).

These studies are based on different contexts, and use various methodologies. these researches do not allow drawing definitive conclusions, and are subjected to debates at both the methodological and technical levels. Therefore, the literature on the impact of remittances seems inconclusive, covering quite varied, complex (sometimes negative or positive or conditional positive or no significant effect) results. De Haas (2005) stipulates that some of these findings may result from the omission of certain relevant variables.

\section{Remittances and Economic Growth in the Sample Countries}

Figure 1 shows that the remittances to Egypt are the highest in our sample. It reaches \$23.68 billion in 2017. Egypt is assumed to be one of the major exporters of migrant workers during that period. It is followed by Lebanon, Morocco and Jordan with 7.77, 6.82 and 4.43 US\$ billions respectively. The remittances flows into Sudan are the lowest among the study sample with $\$ 0.22$ billion. 


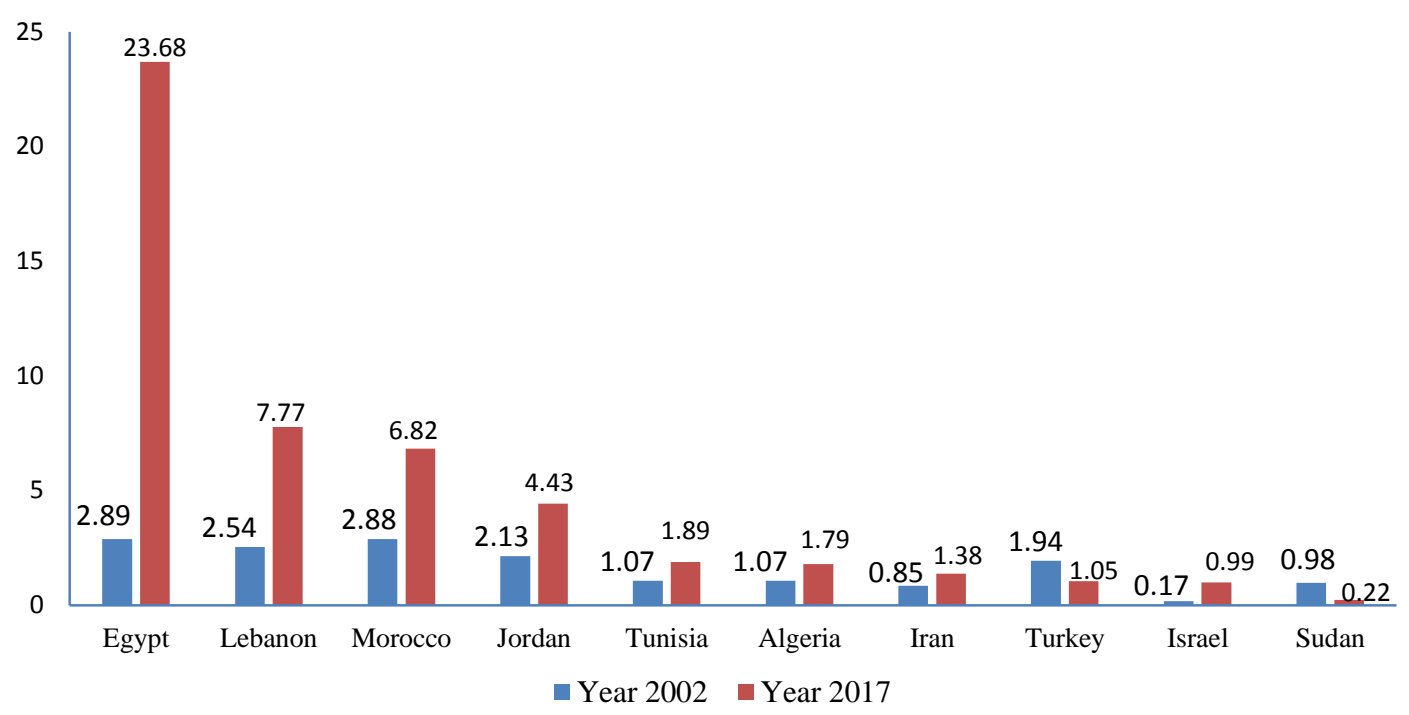

Figure 1. Remittances to countries sample, in billions of USD

However, this order change with the personal remittances as percentage of GDP, received in 2017 (see figure 2). Lebanon registered the highest percentage (13.21\%), followed by Jordan (11.06\%), Egypt (10.06\%), Morocco $(6.22 \%)$ and Tunisia $(4.74 \%)$. The lowest percentage is shown in Turkey with a percentage of $0.12 \%$. Comparing the remittances to the countries sample between the years 2002 and 2017 we notice that they have increased in values in 2017, except for Turkey and Sudan.

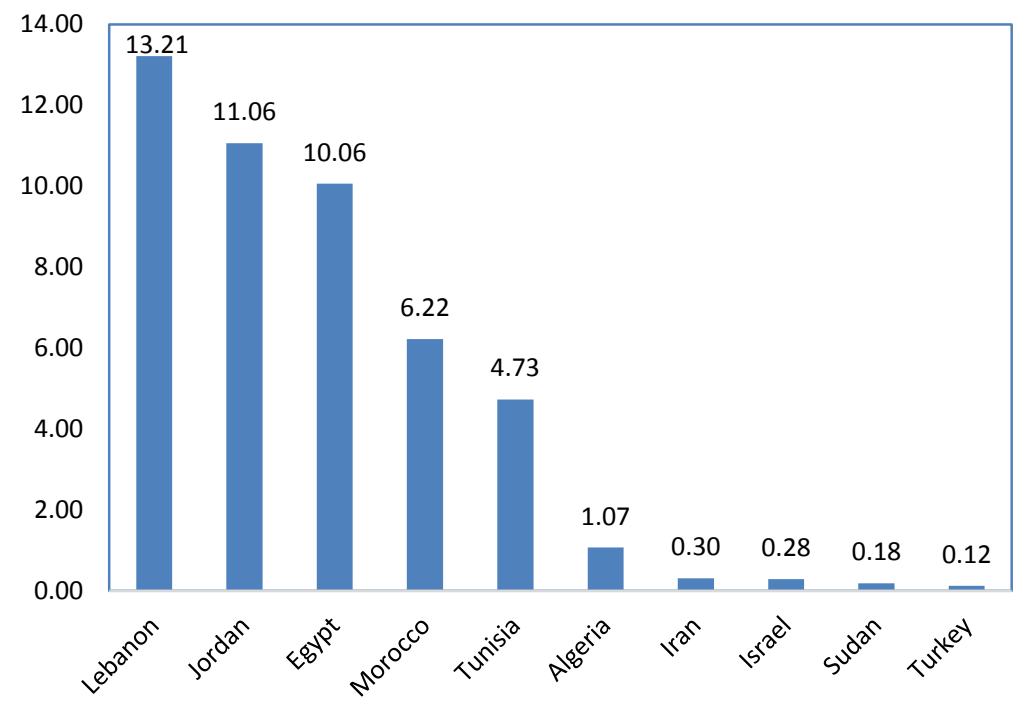

Figure 2. Personal remittances, received (\% of GDP), 2017

Figure 3 indicates that, in 2017, Israel has the highest real GDP per capita $(\$ 34134,81)$, followed by Turkey $(\$ 14936.40)$, Lebanon $(\$ 7102,64)$ and Iran $(\$ 6910.57)$. The remaining countries have a real GDP per capita lower than $\$ 5000$ to reach $\$ 1959.15$ in Sudan. 


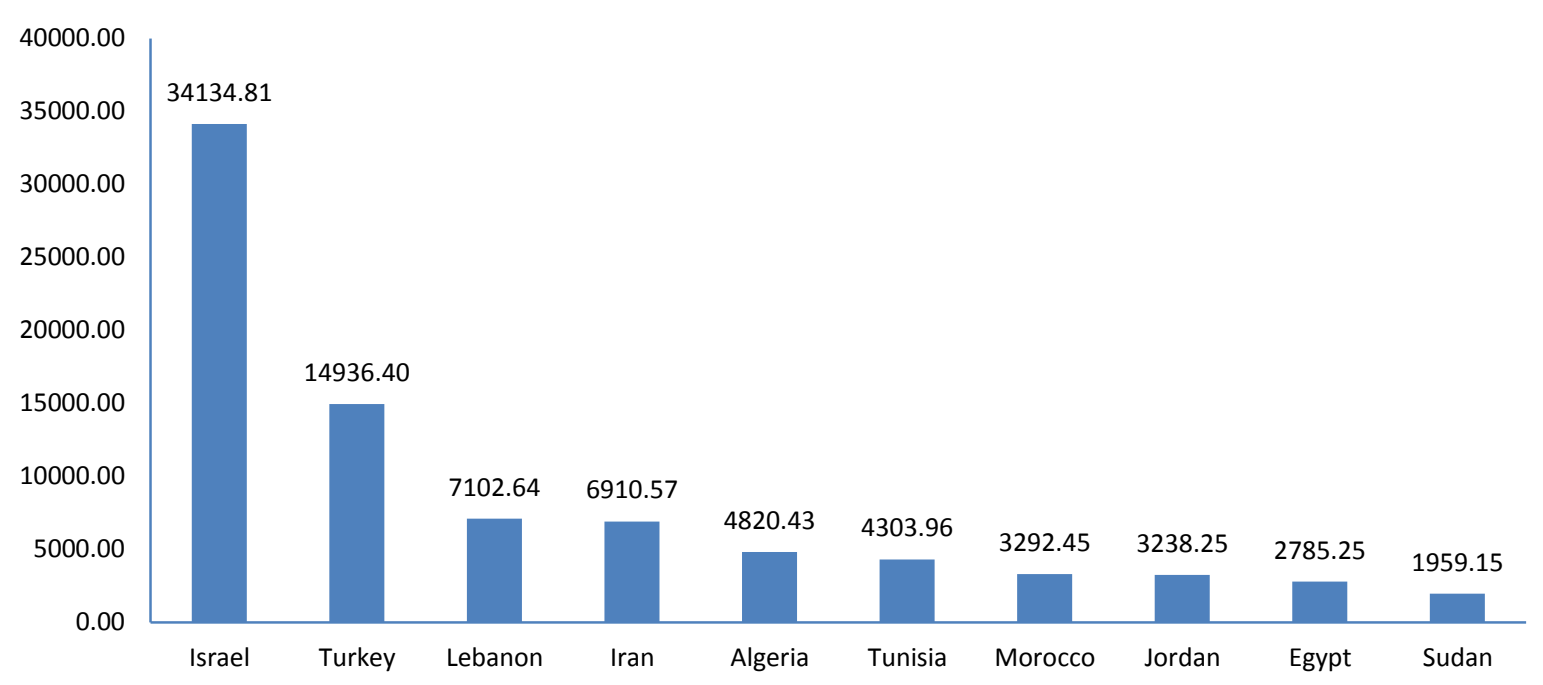

Figure 3. GDP per capita (constant 2010 US\$, 2017) for MENA countries under study

\section{Methodology and Data Description}

\subsection{Data Description}

In order to explore the relationship between Remittances, governance and economic growth in MENA countries, 10 countries are considered as follows: Egypt, Lebanon, Iran, Israel, Tunisia, Jordan, morocco, Algeria, Sudan, and Turkey. We tried to avoid countries with major political problems such as Syria, Yamen and Libya among others.

Annual data from 2002 to 2017 are taken from the world bank. Economic growth is measured by real GDP per capita and considered as dependant variable. The set of independent variables involved in this study consists of:

- The investment, expressed as gross capital formation to GDP, is expected to have a positive impact on GDP per capita

- Population growth, should affect economic growth negatively (Solow, 1956).

- Financial development is proxied by credits to private sector in percentage of GDP. Recent theoretical and empirical researches indicate the presence of a positive impact of financial development on economic growth (Levine, 1997). The financial sector size is mainly determined by the size of an economy. Hence, the financial development is enhanced by the economic growth.

- Openness which stimulates economic growth by facilitating the exchange of goods and services.

- Final government expenditures as percentage of GDP.

- Consumption per capita is assumed to have a positive impact on economic growth.

- Remittances as percent of GDP, this variable could be affected by two main factors that encourage migrants to send more money to their countries: helping their families in periods of recession or for investment motivation.

- Inflation which is expressed by the GDP deflator (base year 2010)

- Governance which is considered as a composite and individual indicators. In order to capture wide information about the governance, we consider the worldwide governance indicators presented by the world bank. These indicators capture six key dimensions of governance: control of corruption, political stability, regulatory quality, rule of law, voice and accountability, and governance effectiveness. Hence, we construct an aggregate indicator of governance as a composite variable that represents the overall features of governance. The resulting variable combines the six abovementioned indicators of governance in the literature. Principal component technique is used to get the required composite.

All variables are expressed in logarithmic form, except for Openness and governance indicators. GDP per capita and consumption per capita are taken in constant 2010 USD.

Descriptive statistics for the variables involved in this study are presented in table 1 . The results show that the 
GDP per capita mean is around $7349.21 \$$, with a maximum of $\$ 34134.81$. However, the MENA zone undergo from great output volatility with a standard deviation of 8203.93\$. As to remittances as percentage of GDP, the mean is $5.76 \%$ over the sample period with a maximum of $26.68 \%$. Remittances reveal also a large volatility with a standard deviation of $6.78 \%$. We notice that the standard deviation in the abovementioned variables is largely greater than the mean over the period 2002-2017.

Table 1. Descriptive statistics of the variables involved in the study (without logarithmic form)

\begin{tabular}{lcccccc}
\hline Variable & Mean & Median & Maximum & Minimum & Standard Deviation & Observations \\
\hline GDP per Capita & 7349.212 & 4270.007 & 34134.81 & 1074.639 & 8203.926 & 160 \\
Gross capital formation (\% of GDP) & 27.3149 & 26.3614 & 50.7091 & 13.6432 & 8.066 & 158 \\
Consumption per capita & 4415.841 & 2439.103 & 19809.44 & 792.401 & 4688.724 & 155 \\
CPI (GDP deflator) & 116.6647 & 100 & 449.1082 & 28.9616 & 61.4883 & 160 \\
Population growth & 2.0389 & 1.7642 & 7.061 & 0.5997 & 1.2306 & 160 \\
Openness & 0.6911 & 0.6508 & 1.4754 & 0.191 & 0.274 & 159 \\
Remittances (\% of GDP) & 5.7593 & 4.237 & 26.6828 & 0.0606 & 6.7812 & 159 \\
Government expenditure (\% of GDP) & 15.6572 & 14.8034 & 26.8475 & 4.5793 & 4.5638 & 159 \\
Credits to private sector (\% of GDP) & 51.0894 & 57.5894 & 105.4751 & 4.5776 & 26.3711 & 158 \\
\hline
\end{tabular}

\subsection{Model and Estimation Methodology}

The first step to do before estimating the appropriate model is to test the stationarity of the variables involved in this study. Several tests are used for this purpose such as Levin, Lin and Chu (2002) and Im, Pesaran and Shin (2003). These tests are widely used in panel studies. The former depends on pooled data and the latter is computed as an average of ADF statistics. We employ also Breitung (2000, 2005), ADF and PP unit root tests for this purpose.

The presence of variables that are stationary at level and others at first, difference leads to the use of the autoregressive distributed lag panel model (ARDL panel model). This technique has the advantage of estimating both short run and long run relationships with error correction coefficient.

To investigate the relationship between remittances and economic growth, we use an autoregressive distributed lag model, $\operatorname{ARDL}(p, q, q, q, q, \ldots, q)$, that is written as follows:

$$
y_{i t}=\sum_{j=1}^{p} \alpha_{i} y_{i t-j}+\sum_{j=0}^{q} \beta_{i j} X_{i, t-j}+\gamma_{i}+\varepsilon_{i t}
$$

where $y_{i t}$ is the dependent variable and $X_{i t}$ is a $k \times 1$ vector of regressors, $\alpha_{i}$ is the coefficient of the lagged dependent variable called scalars, $\beta_{i j}$ are $k \times 1$ coefficient vectors, $\gamma_{i}$ is the country specific fixed effect, $(i=1,2, \cdots, N ; t=1,2, \cdots, T), p, q$ are optimal lag orders, $\varepsilon_{i t}$ is the error term. matrix composed of the control variables above-mentioned, $\gamma_{i}$ is the country specific effect and $\varepsilon_{i t}$ is the error term.

The reparametrized $\operatorname{ARDL}(p, q, q, q, q, \ldots, q)$ error correction model is written as follows:

$$
\Delta y_{i t}=\theta_{i}\left(y_{i, t-1}-\delta_{i}^{\prime} X_{i, t-1}\right)+\sum_{j=1}^{p-1} \mu_{i j} \Delta y_{i t-j}+\sum_{j=0}^{q-1} \beta_{i j}^{\prime} X_{i, t-j}+\gamma_{i}+\varepsilon_{i t}
$$

$\theta_{i}$ is the speed of adjustment coefficient (expected to be negative and significant), $\delta^{\prime}{ }_{i}$ is the vector of the long run relationships. $E C T_{t-1}=\left(y_{i, t-1}-\delta_{i}^{\prime} X_{i, t-1}\right)$ is the error correction term resulting from the long run equilibrium relationship and $\mu_{i j}, \beta_{i j}^{\prime}$ are the short run dynamic coefficients (see Guo, 2017).

\section{Empirical Results}

To investigate the effect of remittances and governance on economic growth we need first to test the stationarity of the series involved in this study. Table 2 reports the results obtained for the different variables. Several unit root tests are used to examine whether the variables are stationary at level or at first difference. The rule of thumb in assuming a stationary series consists in having the majority of tests assuring this stationarity.

The results in table 2 show that some variables are stationary at level (GDP per capita, population growth, Gross capital formation, remittances as \% of GDP, governance composite and control of corruption) while the remaining variables are stationary at first difference (consumption per capita, credits for private sector, openness, CPI, government expenditures, political stability, regulatory quality, governance effectiveness, rule of law and voice and accountability).

The presence of variables integrated of order $0, \mathrm{I}(0)$, and others integrated of order $1, \mathrm{I}(1)$, justifies the use of the panel autoregressive distributed lag model (panel ARDL). In this latter approach, unit root is applied to exclude 
the possibility of I(2) variables (Pesaran et al., 2001). According to the results obtained in table 2 none of the variables is integrated of order $2, \mathrm{I}(2)$. Thus, the use of the panel ARDL to estimate our model appears to be the suitable technique. Long run results are presented in table 3 with the force of adjustment that is supposed to be negative and statistically significant.

Table 2. Test of stationarity of the variables involved in this study

\begin{tabular}{|c|c|c|c|c|c|}
\hline \multirow{3}{*}{ Variable } & \multicolumn{5}{|c|}{ Test of stationarity at level } \\
\hline & \multicolumn{2}{|c|}{ Null: Unit root (assumes common unit root process) } & \multicolumn{3}{|c|}{ Null: Unit root (assumes individual unit root process) } \\
\hline & Levin, Lin \& Chu & Breitung & Im, Pesaran and Shin & ADF & PP \\
\hline Ln(GDP per capita) & $-6.1451 * * *$ & $-2.1247 * *$ & $-2.2468 * *$ & $43.1310 * * *$ & 20.4406 \\
\hline $\begin{array}{l}\text { Ln(Gross Capital Formation } \\
\text { as } \% \text { of GDP) }\end{array}$ & $-5.0033 * * *$ & -0.7165 & $-2.0625^{* *}$ & $34.0415^{* *}$ & 22.2604 \\
\hline Ln(Consumption per Capita) & -0.0162 & 2.2099 & 0.8179 & 16.5528 & 8.3669 \\
\hline Ln(Population Growth) & $-4.1333 * * *$ & 4.0754 & $-5.9873 * * *$ & $66.4210 * * *$ & 13.7280 \\
\hline $\begin{array}{l}\text { Ln(Remittances as } \% \text { of } \\
\text { GDP) }\end{array}$ & $-6.5997 * * *$ & -0.0468 & $-3.9093 * * *$ & $52.7854 * * *$ & $34.6288^{* *}$ \\
\hline $\operatorname{Ln}($ Credits for private sector) & -0.7526 & $-5.2534 * * *$ & -0.1478 & 27.6061 & 30.7046 \\
\hline Openness & $-4.2454 * * *$ & 0.4272 & -1.5982 & 28.1757 & $37.1698^{* *}$ \\
\hline $\operatorname{Ln}(\mathrm{CPI})$ & $-4.8669 * * *$ & 2.6218 & -1.3614 & $32.6263^{* *}$ & 28.0090 \\
\hline Governance Index & $-2.3785^{* * *}$ & 0.8793 & $-1.8752 * *$ & $38.6589 * * *$ & $42.3806^{* * *}$ \\
\hline $\begin{array}{l}\mathrm{Ln} \text { (Government expenditures } \\
\text { as } \% \text { of GDP) }\end{array}$ & $-2.2569 * *$ & 0.7710 & 0.0927 & 16.3784 & 24.8064 \\
\hline Political Stability & $-1.9446^{* *}$ & 0.9239 & -1.2487 & 28.1050 & 27.2825 \\
\hline Regulatory Quality & $-2.6576^{* * *}$ & -0.2663 & -0.7570 & 29.1049 & $32.7211 * *$ \\
\hline Governance Effectiveness & $-3.1622 * * *$ & $-1.7911 * *$ & -1.4409 & 29.3760 & 20.6269 \\
\hline Rule of Law & $-2.5077 * * *$ & 0.6019 & -1.1925 & 29.6875 & 38.0428 \\
\hline Voice and Accountability & $-1.8618 * *$ & 2.3625 & -0.0740 & 20.9451 & 17.9974 \\
\hline Control of Corruption & $-5.4913 * * *$ & -0.2847 & $-2.8432 * * *$ & $37.9208^{* * *}$ & $51.0349 * * *$ \\
\hline
\end{tabular}

Test of stationarity in the first level

\begin{tabular}{|c|c|c|c|c|c|}
\hline & \multicolumn{5}{|c|}{ Test of stationarity in the first level } \\
\hline & \multicolumn{2}{|c|}{ Null: Unit root (assumes common unit root process) } & \multicolumn{3}{|c|}{ Null: Unit root (assumes individual unit root process) } \\
\hline & Levin, Lin \& Chu & Breitung & Im, Pesaran and Shin & $\mathrm{ADF}$ & $\mathrm{PP}$ \\
\hline \multicolumn{6}{|l|}{ Ln(GDP per capita) } \\
\hline \multicolumn{6}{|l|}{$\begin{array}{l}\mathrm{Ln}(\text { Gross Capital Formation } \\
\text { as } \% \text { of GDP) }\end{array}$} \\
\hline Ln(Consumption per Capita) & $-3.4339 * * *$ & -1.0341 & $-2.0799 * * *$ & $39.7146 * * *$ & $52.5076^{* * * *}$ \\
\hline \multicolumn{6}{|l|}{ Ln(Population Growth) } \\
\hline \multicolumn{6}{|l|}{$\mathrm{Ln}($ Remittances as \% of GDP) } \\
\hline $\operatorname{Ln}($ Credits for private sector $)$ & $-6.5674 * * *$ & $-3.2173 * * *$ & $-3.8346 * * *$ & $51.4706 * * *$ & $65.8004 * * *$ \\
\hline Openness & $-6.5181 * * *$ & $-1.7640^{* *}$ & $-3.6154 * * *$ & $49.9181 * * *$ & $90.2366^{* * *}$ \\
\hline $\operatorname{Ln}(\mathrm{CPI})$ & $-4.8630 * * *$ & 0.6134 & $-3.3283 * * *$ & $46.4556 * * *$ & $68.0758 * * *$ \\
\hline \multicolumn{6}{|l|}{ Governance Index } \\
\hline $\begin{array}{l}\mathrm{Ln}(\text { Government expenditures } \\
\text { as } \% \text { of GDP) }\end{array}$ & $-7.0289 * * *$ & $-3.6306 * * *$ & $-3.9029 * * *$ & $49.2552 * * *$ & $57.8373 * * *$ \\
\hline Political Stability & $-9.3521 * * *$ & $-4.6966 * * *$ & $-6.9229 * * *$ & $75.9840 * * *$ & $87.8667 * * *$ \\
\hline Regulatory Quality & $-7.9981 * * *$ & $-3.0954 * * *$ & $-5.3420 * * *$ & $62.7196 * * *$ & $96.7814 * * *$ \\
\hline Governance Effectiveness & $-8.5967 * * *$ & $-5.3027 * * *$ & $-6.4326 * * *$ & $72.8865 * * *$ & $91.0101 * * *$ \\
\hline Rule of Law & $-8.3703 * * *$ & $-4.3002 * * *$ & $-8.0592 * * *$ & $83.3894 * * *$ & $86.4678 * * *$ \\
\hline Voice and Accountability & $-10.3598 * * *$ & $-6.0472 * * *$ & $-6.5249 * * *$ & $73.3091 * * *$ & $91.7052 * * *$ \\
\hline Control of Corruption & & & & & \\
\hline
\end{tabular}

$* * *$, and $* *$ indicate significance at $1 \%$ and $5 \%$ respectively.

In this study eight $\operatorname{ARDL}(1,1,1,1,1,1,1)$ models are estimated. The dependent variable in these models is real GDP per capita. The regressors are divided into two categories. The first one is composed of variables that appear in all models (gross capital formation, consumption per capita, remittances as \% of GDP, credits for private sector and openness). The second one is composed of CPI, government expenditures, governance composite, governance indicators and the interactions of these two latter with the remittances. Variables of the 
second category appear in some models .

The long run results with the coefficients of the ECT are reported in table 3. The results reveal that the coefficient of the error correction term is negative and statistically significant in all specifications. This indicates that these models converge towards equilibrium. The speed of adjustment in these models is between $11 \%$ and $26 \%$. In all models, gross capital formation, consumption per capita and openness have positive and statistically significant impact on GDP per capita (except for model 7 where gross capital formation is not significant). This indicates that higher level of these variables is associated with higher level in economic growth. However, population growth reveals a negative and significant effect on economic growth in all models. In addition, model 1 indicates that public spending has a negative effect on the growth rate of MENA countries. This is in line with the studies done by Jongwanich (2007) and Acosta et al. (2009). It validates the idea that significant government intervention in the economy affects economic growth (Fer \& Henrekson, 2001). Moreover, the estimations show that high inflation is associated with a lower growth rate. As to remittances and governance, they appear to have a negative effect on economic growth. These findings are not in line with the literature, which stipulates a positive effect of remittances on economic growth (Klobodu et al., 2016, Imai et al., 2014, Nyamongo et al., 2012). This suggests that remittances to countries in the MENA region are intended to finance the daily needs of households while compromising their work search or engagement in the implementation of risky investment projects (Ebeke, 2012). This result corroborates that resulting from the work of Chami et al. (2005).

These observations legitimize our questioning about the nature of the relationship that can exist between remittances and economic growth. As a result, it is necessary to examine whether governance and its dimensions influence the impact of remittances on economic growth in MENA countries. We investigate whether there is a relationship of substitutability or complementarity between remittances and the six dimensions of governance in promoting economic growth in MENA countries.

It is assumed that remittances and financial development have a complementary effect in stimulating GDP per capita growth. This suggests that remittances have a positive effect on economic growth only if the national banking system is sufficiently developed. In the light of model 1 , we get a reverse statement. Similar results were obtained by Bettin and Zazzaro (2012) and Nyamongo et al. (2012).

In model 2, the governance composite is integrated in the model with its interaction with remittances. The relationship between these two variables and economic growth is statistically significant at $1 \%$. Transfers negatively affect economic growth while governance is positively related to economic growth. This means that good governance could reduce the negative impact of remittances on economic growth. However, the effect of the interaction term is weak (0.0073) in this specification. Thus, remittances and good governance are assumed to be complements in stimulating economic growth.

In all models, except for models 7 and 8, remittances have a negative and significant effect on GDP per capita. This can be explained by the possibility that remittances may reduce the work effort of beneficiary households since receiving households opt to live of migrants' transfers rather than by working. (El Hamma, 2017; Chami et al., 2005), accelerate inflation (Khan \& Islam, 2013) and appreciate the real exchange rate accompanied by a reallocation of resources from the commercial to non-commercial sector (Amuedo-Dorantes et al., 2010; Bourdet \& Falck, 2006; Acosta et al., 2009). Moreover, it is important to see whether remittances are spent on consumption or are used for productive investments. The former assumption does not necessary affect positively the economic growth, especially when a country is import-oriented. However, the latter assumption spurs the economic growth and plays a potential role on increasing the economic productivity.

If we consider the variables of interest represented by the remittances and their interaction with the governance composite and governance indicators we notice that in model 1 the results reveal a negative impact of remittances and governance composite on economic growth that is statistically significant at $1 \%$.

In models from 3 to 8 , the governance composite is substituted by individual governance indicators as well as the interaction of each indicator with the remittances. Hence, for each model, from 3 to 8 , we use an indicator of governance and its interaction with remittances. This procedure will allow us to better assess which of these components are effective in conveying the effect of remittances to economic growth.

According to the results in table 3, the direct effect of governance variables is positive (with the exception of regulatory quality, voice of accountability and political stability). This suggests that countries in which the level of quality of governance is high register a higher growth rate than those where the level is low. This finding is consistent with the results of El-Hamma (2018) for MENA countries, Farooq et al. (2013) for Pakistan, Agostino et al. (2016) for African countries, Huang (2015) for Asia Pacific countries and Alam (2017) for a panel of 86 countries. 
Table 3. Panel ARDL $(1,1,1,1,1,1,1)$ long run results (dependent variable Real GDP per capita)

\begin{tabular}{|c|c|c|c|c|}
\hline Variable & Model 1 & Model 2 & Model 3 & Model 4 \\
\hline $\operatorname{Ln}($ Gross Capital Formation as \% of GDP) & $0.2670^{* * *}$ & $0.1767 * * *$ & $0.2964 * * *$ & $0.2923 * * *$ \\
\hline Ln(Consumption per Capita) & $1.1191 * * *$ & $1.0703 * * *$ & $0.9413^{* * *}$ & $0.9390 * * *$ \\
\hline Ln(Population Growth) & $-0.4056 * * *$ & $-0.2568 * * *$ & $-0.0345 * * *$ & $-0.1298 * * *$ \\
\hline $\operatorname{Ln}($ Remittances as $\%$ of GDP $)$ & $-0.0232 * * *$ & $-0.0774 * * *$ & $-0.1302 * * *$ & $-0.0752 * * *$ \\
\hline $\operatorname{Ln}($ Credits for private sector $)$ & $0.0419 * *$ & $-0.1423 * * *$ & $-0.0289 * * *$ & $-0.0574 * * *$ \\
\hline Openness & $0.6024 * * *$ & $0.3293 * * *$ & $0.0829 * * *$ & $0.3946^{* * *}$ \\
\hline $\operatorname{Ln}(\mathrm{CPI})$ & $-0.0783 * * *$ & $-0.0217^{*}$ & $0.0186^{*}$ & 0.0046 \\
\hline Governance composite & $-0.0324 * * *$ & $0.0233^{* *}$ & & \\
\hline $\operatorname{Ln}($ Government expenditures as \% of GDP) & $-0.4454 * * *$ & & & \\
\hline (Governance composite)*Ln(Remittances as \% of GDP) & & $0.0073 * * *$ & & \\
\hline Political Stability & & & 0.0011 & \\
\hline (Political Stability)*Ln(Remittances as \% of GDP) & & & $-0.0188 * * *$ & \\
\hline Regulatory Quality & & & & $-0.0082 * * *$ \\
\hline (Regulatory Quality)*Ln(Remittances as \% of GDP) & & & & $-0.1164 * * *$ \\
\hline \multicolumn{5}{|l|}{ Governance Effectiveness } \\
\hline \multicolumn{5}{|l|}{ (Governance Effectiveness) * Ln(Remittances as \% of GDP) } \\
\hline \multicolumn{5}{|l|}{ Rule of Law } \\
\hline \multicolumn{5}{|l|}{ (Rule of Law)*Ln(Remittances as \% of GDP) } \\
\hline \multicolumn{5}{|l|}{ Voice and Accountability } \\
\hline \multicolumn{5}{|l|}{ (Voice and Accountability)* $\operatorname{Ln}($ Remittances as $\%$ of GDP) } \\
\hline \multicolumn{5}{|l|}{ Control of Corruption } \\
\hline \multicolumn{5}{|l|}{ (Control of Corruption)*Ln(Remittances as \% of GDP) } \\
\hline ECT & $-0.1082 * *$ & $-0.1531 * *$ & $-0.2577 *$ & $-0.1701 * * *$ \\
\hline Variable & Model 5 & Model 6 & Model 7 & Model 8 \\
\hline $\mathrm{Ln}($ Gross Capital Formation as \% of GDP) & $0.1274 * *$ & $0.1419^{* * *}$ & 0.0505 & $0.1219 * * *$ \\
\hline Ln(Consumption per Capita) & $1.1042 * * *$ & $1.0568 * * *$ & $1.1700^{* * *}$ & $0.9699 * * *$ \\
\hline Ln(Population Growth) & $-0.1129 * * *$ & $-0.2683 * * *$ & $-0.0409 * * *$ & $-0.3905 * * *$ \\
\hline $\mathrm{Ln}($ Remittances as $\%$ of GDP) & $-0.0370 * *$ & $-0.1027 * * *$ & $-0.1149 * * *$ & $0.1394 * * *$ \\
\hline $\operatorname{Ln}($ Credits for private sector $)$ & $-0.0471 * *$ & $-0.0833 * * *$ & $-0.0963 * * *$ & 0.0215 \\
\hline Openness & 0.0536 & $0.2449 * * *$ & $0.1887 * * *$ & $0.1217 * *$ \\
\hline $\operatorname{Ln}(\mathrm{CPI})$ & & 0.0117 & $-0.2059 * * *$ & \\
\hline \multicolumn{5}{|l|}{ Governance composite } \\
\hline \multicolumn{5}{|l|}{$\operatorname{Ln}($ Government expenditures as \% of GDP $)$} \\
\hline \multicolumn{5}{|l|}{ (Governance composite)* $\operatorname{Ln}($ Remittances as $\%$ of GDP) } \\
\hline \multicolumn{5}{|l|}{ Political Stability } \\
\hline \multicolumn{5}{|l|}{ (Political Stability)* $\operatorname{Ln}($ Remittances as \% of GDP) } \\
\hline \multicolumn{5}{|l|}{ Regulatory Quality } \\
\hline \multicolumn{5}{|l|}{ (Regulatory Quality)* $\operatorname{Ln}($ Remittances as $\%$ of GDP) } \\
\hline Governance Effectiveness & $0.1757 * * *$ & & & \\
\hline (Governance Effectiveness) * $\operatorname{Ln}($ Remittances as \% of GDP) & $0.0418 * * *$ & & & \\
\hline Rule of Law & & $0.0619^{*}$ & & \\
\hline$($ Rule of Law)*Ln(Remittances as \% of GDP) & & 0.0171 & & \\
\hline Voice and Accountability & & & $-0.2187 * * *$ & \\
\hline (Voice and Accountability)* $\operatorname{Ln}($ Remittances as $\%$ of GDP) & & & $0.0299 * * *$ & \\
\hline Control of Corruption & & & & $-0.3765 * * *$ \\
\hline (Control of Corruption)*Ln(Remittances as \% of GDP) & & & & $0.1396^{* * *}$ \\
\hline ECT & $-0.1538 * *$ & $-0.1904 * * *$ & $-0.1532 *$ & $-0.1521 * *$ \\
\hline
\end{tabular}

In models 3 and 4, the interaction between remittances and political stability, from one hand, and remittances and regulatory quality, on the other hand, have a negative impact on economic growth. This could be explained by the reduction of informal remittances that flow into the country easily in situation of political instability and weak regulations. MENA regions is known as a continuously unstable region. This political instability pushes remitters to send more money to their families for consumption purpose since this situation is usually accompanied by a high level of unemployment and high emigration rate of skilled and highly educated persons. Remittances come to compensate the monetary shortfalls resulting from these issues. 
In models 5, 6 and 7 the interaction between remittances and each of governance effectiveness, rule of law and voice of accountability has a positive and statistically significant impact on economic growth. This is due to the transmission of migrant norms, behaviours and attitudes at the household level (non-monetary remittances). The reduced costs of transportation and communications allow migrants to remain in continued contact with their relatives in the country of origin and to participate in the social, economic and political life in both countries (at home and abroad). In this way, migrants could influence political and institutional processes in their country of origin (Burgess, 2012; Philips, 2012). This influence takes the name of social remittances that can be expressed as ideas, practices, identities and social capital that migrants internalise in the host country and remit to their countries of origin (levitt, 1998). However, Levitt states that good and bad practice can be transmitted but migrants who send monetary remittances are more efficient in influencing social behaviour of their family members.

In model 8, the control of corruption has a negative and statistically significant effect on economic growth. While the impact of the interaction between remittances and control of corruption on economic growth is positive and statistically significant at $1 \%$. This can be explained by the fact that migrants who work in a country that is characterized by relatively high control of corruption, compared to the country of origin, may transfer good practice from the host to the home country (this is called value effect). However, the relatives of the migrants who receive the monetary remittances may have relatively larger financial resources and be more willing and able to pay a bribe, for instance, to public officials in order to get an accelerated and high -quality public service (monetary effect). In addition, remittance recipients may be a prime extortion target for corruption-prone public officials - again, because of the larger financial resources that people with migration connections are often associated with. Such monetary channels will, arguably, result in a detrimental impact of migration on the incidence of corruption.

The control of corruption in the context of the considered countries contributes to favoring the positive impact of transfers on economic growth. This result seems to validate the idea that administratively located corruption helps to stimulate economic growth while reducing rigidities (Aidt et al., 2008). In addition, it confirms the result of Wang and You (2012) according to which a number of countries very affected by corruption display exceptionally high growth rates, like China. On the other hand, when it is concentrated at the political level, it has a detrimental effect on growth since the resources that are diverted by the government reduce the well-being of the society (Leff, 1964). It seems that remittances are intended to finance the current consumption of beneficiary families in MENA countries. As a result, they contribute to compromising labor supply, productivity and the realization of investment projects.

MENA countries involved in this study are known to have high prevalence of corruption. As a result, the remittances in this sense has a positive and statistically significant effect on economic growth.

All in all, the use of the six governance indicators in the models 3-8, in term of their interaction with remittances, has resulted in different impacts on economic growth. Three of them show a positive impact on economic growth and the remaining three indicators reveal a negative impact. All the coefficients of these interactions are statistically significant. It can therefore be concluded that governance dimensions do not influence the relationship between transfers and growth in the same way. On the other hand, it is important to notice that in the MENA countries, the political situation as well as the regulatory quality consist in governance indicators that aggravate the negative impact of the transfer of funds on economic growth. In addition, it seems that corruption is more concentrated at the administrative level than the political one.

\section{Conclusion}

The effect of emigration on the country of origin is not limited to the money remittances only but also to the remittances of ideas, institutional arrangements, norms and attitudes. These intangibles are transmitted by emigrants through the correspondence, visits and return to home country. They exert remarkable influence and change on the development of the country of origin by spreading the behavioural norms and institutional arrangement absorbed and internalised in their attempts to prosper in the receiving country (Levitt, 2001). As a results, we can distinguish two aspects of the remittances: monetary and non-monetary (social, political or institutional remittances). These latter can be revealed in the control of corruption governance effectiveness, regulatory role and quality of law. This paper investigates whether remittances in its twofold aspects have an effect on economic growth.

Previous studies have shown conflicting results. These differences stem from the use of different empirical frameworks, from the presence of different institutional aspects and various structural features among countries under study. 
Using eight panel ARDL models, this paper has investigated the relationship between GDP per capita and the following variables: remittances, credits for private sector, openness, consumption per capita, the interaction between remittance and a composite of governance. This later latter was substituted by the interaction between remittances and the 6 governance indicators. Ten MENA countries are considered to do this research and annual data are taken from 2002 to 2017 . Thus, we estimated eight models to test the hypothesis that the effect of remittances on economic growth depends on the quality of governance.

The results indicate that remittances have globally negative impact on economic growth due the use of the transfer of funds mainly on the consumption. Moreover, the interaction between remittances and each of governance composite, governance effectiveness, rule of law, voice and accountability and control for corruption show a positive impact on economic growth. This implies that a higher level of institutional quality (enforcement of contracts, property rights, absence of corruption) could reassure migrants and recipient households about the situation in their country and therefore encourage their initiatives to invest, innovate contribute to economic activity. However, the interaction between remittances and political stability and regulatory quality appears to be negative. This finding stems from the fact that situations with political instability and poor regulatory quality encourage the transfers of funds in informal channels. The presence of political stability and enhanced regulatory quality could reduce these informal remittances remarkably. In addition, the propensity of migrants to remit (again, particularly through formal channels) may depend on the institutional, cultural, and informational gaps between migrants and the host country's financial system (Albareto \& Mistrulli, 2011).

The findings of this study indicate that the remittances are mainly directed to consumption and since Lebanon is an import-oriented country, the economic growth is negatively affected by the remittances. Hence, encouraging the investment activities is a major step to enhance the economic growth. This could be realized by decreasing the interest rate and dispensing the starts ups from the taxes for a limited time. Moreover, it is very importance to enhance the governance in all countries under study since they suffer from bad governance in all its dimension. The obtained results revealed the positive impact of the governance composite on economic growth thereby divulges the importance of enhancing the indicators involved in the governance. This paper highlights an important issue for policymakers. The obtained results could help them to put appropriate strategies to booster relatively the economic growth and reduce the obstacles that deter the flow of remittances into the recipient countries.

\section{Acknowledgments}

This project has been jointly funded with the support of the National Council for Scientific Research in Lebanon CNRS-L and Lebanese University.

\section{References}

Abdih, Y., Chami, R., Dagher, J., \& Montiel, P. (2012). Remittances and Institutions: Are Remittances a Curse? World Development, 40(4), 657-666. https://doi.org/10.1016/j.worlddev.2011.09.014

Acosta, P. A., Baerg, N. R., \& Mandelman, F. S. (2009). Financial development, remittances, and real exchange rate appreciation. Federal Reserve Bank of Atlanta Economic Review, 94(1), 14.

Acosta, P. A., Lartey, E. K. K., \& Mandelman, F. S. (2009). Remittances and the Dutch disease. Journal of International Economics, 79(1), 102-116. https://doi.org/10.1016/j.jinteco.2009.06.007

Adams, R. H. Jr. (2003). International migration, remittances, and the brain drain: A Study of 24 labor-exporting countries. World Bank, Policy Research Working Paper N 3069. https://doi.org/10.1596/1813-9450-3069

Adams, R. H., Jr. \& Cuecuecha, A. (2013). The impact of remittances on investment and poverty in Ghana. World Development, 50, 24-40. https://doi.org/10.1016/j.worlddev.2013.04.009

Adams, S., \& Klobodu, E. K. M. (2016). Remittances, regime durability and economic growth in Sub-Saharan Africa (SSA). Economic Analysis and Policy, 50, 1-8. https://doi.org/10.1016/j.eap.2016.01.002

Agostino, G. D', Dunne, J. P., \& Pieroni, L. (2016). Corruption and growth in Africa. European Journal of Political Economy, 43, 71-88. https://doi.org/10.1016/j.ejpoleco.2016.03.002

Ahamada, I., \& Coulibaly, D. (2013). Remittances and growth in sub-saharan african countries: Evidence from a panel causality test. Journal of International Development, 25(3), 310-324. https://doi.org/10.1002/jid.2830

Aitymbetov, S. (2006). Emigrant remittances: impact on economic development of Kyrgyzstan. ICEG European Center, Working Paper $\mathrm{N}^{\circ} 31$. https://doi.org/10.1787/9789264013896-7-en

Akobeng, E. (2016). Out of inequality and poverty: Evidence for the effectiveness of remittances in Sub-Saharan 
Africa. The Quarterly Review of Economics and Finance, 60, 207-223. https://doi.org/10.1016/j.qref.2015.10.008

Alam, M. R., Kitenge, E., \& Bedane, B. (2017). Government effectiveness and economic growth. Economics Bulletin, 37(1), 222-227.

Albareto, G., \& Mistrulli, P. (2011). Bridging the gap between migrants and the banking system. Temi di discussione (Economic working papers) 794, Bank of Italy, Economic Research and International Relations Area. https://doi.org/10.2139/ssrn.1830082

Amuedo-Dorantes, C., \& Mazzolari, F. (2010). Remittances to Latin America from migrants in the United States: Assessing the impact of amnesty programs. Journal of Development Economics, 91(2), 323-335. https://doi.org/10.1016/j.jdeveco.2009.06.006

Amuedo-Dorantes, C., Georges, A., \& Pozo, S. (2010). Migration, remittances, and children's schooling in Haiti. The ANNALS of the American Academy of Political and Social Science. https://doi.org/10.1177/0002716210368112

Ang, A. (2009). Workers' remittances and its impact on rural development in the Philippines. Asia-Pacific Social Science Review, 9(2), 63-77. https://doi.org/10.3860/apssr.v9i2.1462

Arellano, M., \& Bond, S. (1991). Some tests of specification for panel data: Monte Carlo evidence and an application to employment equations. The Review of Economic Studies, 58(2), 277-297. https://doi.org/10.2307/2297968

Ayana Aga, G., \& Martinez Peria, M. S. (2014). International remittances and financial inclusion in Sub-Saharan Africa. World Bank, Policy Research Working Paper N 6991. https://doi.org/10.1596/1813-9450-6991

Barajas, A., \& Chami, R. (2009). Do Workers' Remittances promote economic growth? IMF Working Papers $\mathrm{N}^{\circ}$ 09. https://doi.org/10.5089/9781451873009.001

Barro, R. J. (1991). Economic growth in a cross section of countries. The Quarterly Journal of Economics, 106(2), 407. https://doi.org/10.2307/2937943

Barro, R. J. (1996). Determinants of economic growth: a cross-country empirical study. NBER Working Paper 5698. https://doi.org/10.3386/w5698

Barro, R. J., \& Sala-I-Martin, X. (2003). Economic growth (2nd Ed.). Cambridge, Massachusetts: The MIT Press.

Bekaert, G., Harvey, C. R., \& Lundblad, C. (2006). Growth volatility and financial liberalization. Journal of International Money and Finance, 25(3), 370-403. https://doi.org/10.1016/j.jimonfin.2006.01.003

Bettin, G., \& Zazzaro, A. (2012). Remittances and financial development: Substitutes or complements in economic growth? Bulletin of Economic Research, 64(4), 509-536. https://doi.org/10.1111/j.1467-8586.2011.00398.x

Blundell, R., \& Bond, S. (1998). Initial conditions and moment restrictions in dynamic panel data models. Journal of Econometrics, 87(1), 115-143. https://doi.org/10.1016/s0304-4076(98)00009-8

Bollen, K. A. (1995). Structural Equation Models That are nonlinear in latent variables: A least-squares estimator. Sociological Methodology, 25, 223-251. https://doi.org/10.2307/271068

Bourdet, Y., \& Falck, H. (2006). Emigrants' remittances and Dutch Disease in Cape Verde. International Economic Journal, 20(3), 267-284. https://doi.org/10.1080/10168730600879323

Breitung, J. (2000). The local power of some unit root tests for panel data. In B. Baltagi (Ed.), nonstationary panels, panel cointegration, and dynamic panels. Advances in Econometrics, 15, 161-178. https://doi.org/10.1016/s0731-9053(00)15006-6

Breitung, J. (2005). A parametric approach to the estimation of cointegration vectors in panel data. Econometric Reviews, 151-174. https://doi.org/10.1081/etc-200067895

Burgess, K. (2012). Migrants, remittances and politics: Loyalty and Voice after Exit. Fletcher Forum of World Affairs, 36(1), 43-55

Burgess, R., \& Haksar, V. (2005). Migration and foreign remittances in the Philippines. IMF Working Papers 2005/111, 1-18. https://doi.org/10.5089/9781451861303.001

Calero, C., Bedi, A. S., \& Sparrow, R. (2009). Remittances, liquidity constraints and human capital investments 
in Ecuador. World Development, 37(6), 1143-1154. https://doi.org/10.1016/j.worlddev.2008.10.006

Catrinescu, N., Leon-Ledesma, M., Piracha, M., \& Quillin, B. (2009). Remittances, institutions, and economic growth. World Development, 37(2139), 81-92. https://doi.org/10.1016/j.worlddev.2008.02.004

Chami, R., Fullenkamp, C., \& Jahjah, S. (2005). Are Immigrant remittances flows a source of capital for development? IMF Working Papers 03/189, 55-81. https://doi.org/10.5089/9781451859638.001

Combes, J. L., \& Ebeke, C. (2011). Remittances and household consumption instability in developing countries. World Development, 39(7), 1076-1089. https://doi.org/10.1016/j.worlddev.2010.10.006

Edwards, A. C., \& Ureta, M. (2003). International migration, remittances, and schooling: Evidence from El Salvador. Journal of Development Economics, 72(2), 429-461. https://doi.org/10.3386/w9766

El Hamma, I. (2017). Do political institutions improve the effect of remittances on economic growth? Evidence South - Mediterranean countries. Economics Bulletin, 37(3), 2133-2148. Retrieved from https://econpapers.repec.org/RePEc:ebl:ecbull:eb-17-00318

El Hamma, I. (2018). Migrant Remittances and Economic Growth: The Role of Financial Development and Institutional Quality. Economie et Statistique / Economics and Statistics, 503-504. https://doi.org/10.24187/ecostat.2018.503d.1961

El Qorchi, M., Munzele, M. S., \& Wilson, J. F. (2003). Informal funds transfer systems: An analysis of the informal Hawala System. IMF Occasional Paper $\mathrm{N}^{\circ} 222$. https://doi.org/10.5089/9781589062269.084

Fayissa, B., \& Nsiah, C. (2012). Financial development and remittances in Africa and the Americas: A panel unit-root tests and panel cointegration analysis. Middle Tennessee State University, Department of Economics and Finance, Working Papers 201201. https://doi.org/10.1007/s12197-011-9195-6

Fölster, S., \& Henrekson, M. (2001). Growth effects of government expenditure and taxation in rich countries. European Economic Review, 45(8), 1501-1520. https://doi.org/10.1016/s0014-2921(00)00083-0

Giuliano, P., \& Ruiz-Arranz, M. (2009). Remittances, financial development, and growth. Journal of Development Economics, 90(1), 144-152. https://doi.org/10.1016/j.jdeveco.2008.10.005

Glytsos, N. P. (2005). The contribution of remittances to growth: A dynamic approach and empirical analysis. Journal of Economic Studies, 32(6), 468-496. https://doi.org/10.1108/01443580510631379

Gubert, F. (2002). Do migrants insure those who stay behind? Evidence from the kayes area (Western Mali). Oxford Development Studies, 30(3), 267-287. https://doi.org/10.1080/1360081022000012699

Guillaumont Jeanneney, S., \& Kpodar, K. (2006). Développement financier, instabilité financière et croissance économique. Economie \& Prévision, 174(3), 87-111. https://doi.org/10.3406/ecop.2006.7954

Guo, Z. (2017). Comparison of Error Correction Models and First-Difference Models in CCAR Deposits Modelling. Global Journal of Management and Business Research, 17(3), 13-31. https://doi.org/10.2139/ssrn.3013799

Huang, C. J. (2016). Is corruption bad for economic growth? Evidence from Asia-Pacific countries. The North American Journal of Economics and Finance, 35, 247-256. https://doi.org/10.1016/j.najef.2015.10.013

Im, K. S., Pesaran, M. H., \& Shin, Y. (2003). Testing for unit roots in heterogeneous panels. Journal of Econometrics, 115(1), 53-74. https://doi.org/10.1016/s0304-4076(03)00092-7

Imai, K. S., Gaiha, R., Ali, A., \& Kaicker, N. (2014). Remittances, growth and poverty: New evidence from Asian countries. Journal of Policy Modeling, 36(3), 524-538. https://doi.org/10.1016/j.jpolmod.2014.01.009

Jongwanich, J. (2007). Workers' remittances, economic growth and poverty in developing Asia and the pacific

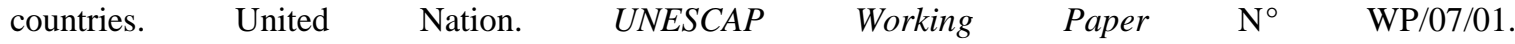
https://doi.org/10.1355/9789814762281-008

Khan, Z. S., \& Islam, S. (2013). The effects of remittances on inflation: Evidence from Bangladesh. Journal of Economics and Business Research, 19(2), 198-208.

Levin, A., Lin, C. F., \& Chu, C. S. J. (2002). Unit root tests in panel data: Asymptotic and finite-sample properties. Journal of Econometrics, 108(1), 1-24. https://doi.org/10.1016/s0304-4076(01)00098-7

Levine, R. (1997). Financial development and economic growth: Views and Agenda. Journal of Economic Literature, 35(2), 688-726. https://doi.org/10.1596/1813-9450-1678

Levitt, P. (1998). Social remittances: Migration driven local-level forms of cultural diffusion. International 
Migration Review, 32(4), 926-948. https://doi.org/10.1177/019791839803200404

Levitt, P. (2001). The Transnational Villagers. University of California Press. https://doi.org/10.1177/08969205010270030806

Lucas, R. E. B. (2005). International Migration and Economic Development: Lessons from Low-Income Countries. Cheltenham, UK and Northampton, MA, USA: Edward Elgar. https://doi.org/10.25336/p6ds45

Majeed, M. T. (2015). Poverty effects of remittances: A comparative analysis. Journal of International Development, 27(1), 1-14. https://doi.org/10.1002/jid.3055

Mundaca, B. G. (2009). Remittances, financial market development, and economic growth: The case of Latin America and the Caribbean. Review of Development Economics, 13(2), 288-303. https://doi.org/10.1111/j.1467-9361.2008.00487.x

Nyamongo, E. M., Misati, R. N., Kipyegon, L., \& Ndirangu, L. (2012). Remittances, financial development and economic growth in Africa. Journal of Economics and Business, 64(3), 240-260. https://doi.org/10.1016/j.jeconbus.2012.01.001

Pesaran, M. H. (2007). A simple panel unit root test in the presence of cross-section dependence. Journal of Applied Econometrics, 22(2), 265-312. https://doi.org/10.1002/jae.951

Pesaran, M. H., Shin, Y., \& Smith, R. (2001). Bounds testing approaches to the analysis of level relationships. Journal of Applied Econometrics, 16, 289-326. https://doi.org/10.1002/jae.616

Phillips, D. L. (2012). Liberating Kosovo: Coercive diplomacy and U.S. intervention (p. 256). Cambridge: MIT Press. https://doi.org/10.7551/mitpress/9590.001.0001

Rapoport, H., \& Docquier, F. (2005). The Economics of Migrants' Remittances. In M. Ythier \& S. Kolm (Eds.), Handbook on the Economics of Giving, Reciprocity and Altruism (pp. 1135-1198). Amsterdam, London: North Hollande. https://doi.org/10.1016/s1574-0714(06)02017-3

Singh, R. J., Haacker, M., Lee, K. W., \& Le Goff, M. (2011). Determinants and Macroeconomic Impact of Remittances in Sub-Saharan Africa. Journal of African Economies, 20(2), 312-340. https://doi.org/10.1093/jae/ejq039

Woodruff, C., \& Zenteno, R. (2007). Migration networks and microenterprises in Mexico. Journal of Development Economics, 82(2), 509-528. https://doi.org/10.1016/j.jdeveco.2006.03.006

World Bank. (2016). Migration and Development Brief 23. Washington, DC: World Bank.

World Bank. (2018). Migration and Development Brief 29. Washington, DC: World Bank.

Ziesemer, T. H. W. (2012). Worker remittances, migration, accumulation and growth in poor developing countries: Survey and analysis of direct and indirect effects. Economic Modelling, 29(2), 103-118. https://doi.org/10.1016/j.econmod.2011.08.013

\section{Notes}

Note 1. In terms of impact, three main fields are explored: (1) the impact on income distribution, poverty reduction and individual well-being (2) the impact on the trade balance deficits and the balance of current operations (3) and the impact on the economy in general, by examining the effects on employment, productivity and above all economic growth.

Note 2. Income, level of education, marital status, age, sex, duration, costs of migration, spouse and wealth of migrants.

\section{Copyrights}

Copyright for this article is retained by the author(s), with first publication rights granted to the journal.

This is an open-access article distributed under the terms and conditions of the Creative Commons Attribution license (http://creativecommons.org/licenses/by/4.0/). 